fact that when he first went to the Department of Physical Chemistry at Sheffield in 1904, Dr. Peddle was his first honours student, and later his first research student, and that one of his early students was Dr. S. English, who is president-elect of the Society. Attention was directed to the fact that the painting of the portrait was made possible by gifts from 417 members of the Society, represent. ing eighteen different countries, including some of those with which we are now at war. Coloured photographic replicas of the portrait have been made, and one of these is being kept by Prof. Turner and the other is being sent to the United States, where it will hang in the building of the American Ceramic Society at Columbus, Ohio. Finally, Prof. Turner offered the portrait to the University of Sheffield and this was accepted by Sir Henry Stephenson, pro-chancellor of the University.

\section{Science and the War Effort}

THE Association of Scientific Workers is organizing an open conference on the general topic of "Science and the War Effort", to be held in the Caxton Hall, Westminster, during January 10 and 11, 1942. The president of the Association, Mr. R. A. Watson Watt, will open the Conference at 10 a.m. on January 10. The proceedings will then develop in two parallel sessions ; one session will be concerned with technical education, which will include the university training of men of science and technicians, also the special technical training of personnel for the Forces and for industry. The parallel session will be discussing building, housing and A.R.P. in the morning; and, during the afternoon, food and agriculture. After tea, both sessions will unite for the main discussion on the latter subject. The session on January 11 will be entirely devoted to discussion of immediatie scientific problems in relation to war production and the services. One topic which will be thoroughly examined is the utilization of scientific personnel, about which subjest the Industrial Committee of the Association has collected a great deal of material. The remainder of the day will be occupied with the examination of the application of scientific knowledge to production problems and to services problems. This will include consideration of industrial health, conditions of work, and related topics. The final session after tea will be devoted to summing up the results of the Conference.

A feature of the proceedings will be the ample provision for discussion, both during the sessions themselves, and in the tea intervals. It is hoped that members of the general scientific, engineering and technical community will avail themselves of this opportunity. It should be noted that this is the first open conference to be held in Great Britain of scientific workers to discuss their part in the national effort. The Conference Sub-Committee will welcome inquiries and suggestions, both from individuals and from scientific and technical bodies. All communications should be addressed to the Conference Secretary, Association of Scientific Workers, 30 Bedford Row, W.C.1.

\section{American Mathematics and the U.S.S.R.}

THe following reply to the message sent by American mathematicians to their colleagues in the U.S.S.R. (see NATURE of November 8, p. 560) was sent from Moscow on October 7 :

"Your splendid message, dear colleagues, found wide response in the hearts of the scientists of our country. We read it with feelings of all the more appreciation and satisfaction in that it again emphasized the community of thoughts and the friendly ties between the mathematicians of the U.S.A. and the U.S.S.R. Many years we jointly worked with you on the development of our science, many of our American colleagues were our welcomed guests, while with a still greater number of American scientists we conduct friendly scientific correspondence. This mutual co-operation was very fruitful and led to a number of important scientific discoveries. In recent years our country became the centre of gravity for eminent European mathematicians who were forced to flee the lands downtrodden by the heel of Nazi barbarians. Our country too is subjected to the invasion of these gloomy medieval forces. The Hitlerites seek to smash the U.S.S.R. in order to make their forces afterwards available for destroying also your great country. The fight now being waged by our people is the fight for the progress of all mankind, for everything advanced, the fight for the flourishing of civilization and of science.

"Our science too has been placed at the service of our country for the destruction of Nazism. Soviet mathematicians, like all Soviet scientists, participate in this fight in common with the whole people. This struggle of Soviet scientists is the common cause of the scientists of all democracies, against the fiend who shoots children, burns libraries, smashes universities, and destroys science. On this momentous day your message, dear friends, has been received by us as the proof of the unity of Soviet and American scientists and their determination to fight the twentieth-century vandals till the end. Let the friendship of the Soviet and the American scientists be the surety of the friendship of our great nations, the surety of the victory of democracy over the dark forces of Hitlerism."

The message was signed by sixty-four Russian mathematicians including A. Sobelev, director of the Steklov Mathematical Institute of the Academy of Sciences of the U.S.S.R., and P. Alexandrov, president of the Moscow Mathematical Society.

\section{Colonial Affairs}

Mr. G. H. HALL, Under-Secretary of State for the Colonies, made a statement on Colonial policy in the House of Commons on November 20. After a striking tribute to the "universal uprush of loyalty to the Throne and support for our cause in all the peoples of the Colonial Empire", Mr. Hall announced that it has been decided to appoint a Colonial Labour Advisory Committee, to function on the lines of the committees already in existence on medical matters and on education. The Committee, which will be a 
small one, will consist of representatives of the Colonial Office, and members of the Trades Union Congress and of employers' organizations interested in Colonial affairs. The Colonial Office already has a labour adviser, and the new Committee will serve to strengthen this side of its work. It may be anticipated that as the various provisions of the Welfare and Development Act come more extensively in force, this Committee will grow in importance and its activities play a prominent part in the future of the British Colonial Empire.

A brief survey of Colonial Office activities during the past year was also given by Mr. Hall. Even under war-time conditions it has been possible to send officials of the Colonial Office overseas to examine problems on the spot. Lord Hailey is presiding over a committee examining post-war problems which are likely to arise. Many schemes, amounting to hundreds of thousands of pounds, submitted under the Welfare and Development Act, have been approved. The appointment of an economic and financial adviser to work with Sir Frank Stockdale is being considered. The needs of Colonial peoples in Great Britain have also been examined; a welfare officer and an assistant welfare officer, the latter an African, have been appointed, and an adviser to Colonial students, who is a West Indian, is being appointed. Mr. Hall concluded by emphasizing that our duty is now to improve the lot of the Colonial peoples, to develop their resources so as to raise their standard of living, and to enable them to take an ever-increasing responsibility in their own government.

\section{Federation of American Societies for Experimental Biology}

Is March 1942 the Federation of American Societies for Experimental Biology will issue the first number of a quarterly publication to be named the Federation Proceedings. This will be published by an editorial board representing the five constituent societies of the Federation : the American Physiological Society, the American Society of Biological Chemists, the American Society for Pharmacology and Experimental Therapeutics, the American Society for Experimental Pathology, and the American Institute of Nutrition. Four numbers will be published each year. The March issue will appear just previous to the annual meeting of the Federation, and will be composed of two parts. Part 1 will include the abstracts of all the papers to be presented at the annual meeting, about a thousand in all. Part 2 will comprise the programme of the scientific sessions of all the constituent societies of the Federation. The June and September issues will include the full text of perhaps twenty of the papers presented at the annual meeting as selected by the editorial board, including probably the papers on the joint programme of the Federation as a whole as well as the papers of one symposium of each of the five societies. The December issue will include material pertinent to the Federation membership formerly published in the Federation Yearbook, which will hereafter be discontinued. The Federation Proceedings will be distributed without further charge to all members of the Federation. The subscription price to non-members will be four dollars (4.50 dollars foreign) payable in advance. Further information can be obtained from Dr. D. R. Hooker, Managing Editor, 19 West Chase Street, Baltimore, Maryland.

\section{Therapeutic Research Corporation}

A NEW step in the rationalization of the British fine chemical industry has been taken by the formation of the Therapeutic Research Corporation of Great Britain, Ltd., the directors of which are Lord Trent, of Boots Pure Drug Company, Ltd., Mr. C. A. Hill, of the British Drug Houses, Ltd., Mr. H. Jephcott, of Glaxo Laboratories, Ltd., Mr. T. B. Maxwell, of May and Baker, Ltd., and Mr. T. R. G. Bennett, of the Wellcome Foundation, Ltd. Although each of the directors of the new Corporation is managing director of his own concern, the Corporation is not an amalgamation of these five firms. Each will retain its freedom of action in its special field, but will contribute to the common research pool ; in effect, a much extended research team now becomes available for work on new drugs, and overlapping effort should be eliminated. It is also hoped to secure the interest and co-operation of research workers in academic institutions. The Corporation will have in the various chemical, physiological and bacteriological laboratories at its command the choice of many differęnt lines of approach to its problems and the call on the extensive scientific personnel and equip. ment of the five companies which are collaborating. This should make for a hopeful start and lay the foundation of a promising superstructure.

\section{Norway: Present and Future}

Mr. GATHORNE-HARDY's pamphlet. "Norway and the War" (Oxford Pamphlets on World Affairs, No. 51. 4d. net) gives an account of the physical characteristics and resources of Norway, its people and their democracy, and relations with their Scandinavian neighbours and other powers, which could scarcely be bettered as a contribution to the understanding of the Norwegian resistance to Nazism and of Norway's future. Although little more than a third of the pamphlet deals with Norway and the War proper, the pamphlet contains nothing irrelevant, and it emphasizes the close ties between Norway and Great Britain through the marked similarity of outlook, the ties of the sea, and the long association of various kinds.

Despite the appeal of Germany in scientific and technical circles, Norwegian thought, with its passionate insistence on individual liberty, free speech and parliamentary democracy, is diametrically opposed to the totalitarian ideology, and her neutrality had no spiritual basis. Mr. GathorneHardy emphasizes the important part which confusion, rather than deliberate treachery, played in the situation when Norway was invaded, and also the credit due to the Norwegians for the toughness of their resistance in a singularly desperate situation. After a brief account of the German occupation, he 